MA

Modern European
Philosophy

Apply now to start next September on our twoyear evening programme

\section{FREEPHONE 0800181170}

or write: Enquiries

(ref C342A)

Middlesex University

London N17 8HR

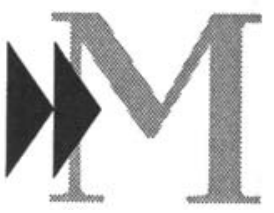

MIDDLESEX UNIVERSITY

A unique opportunity to develop your understanding of European philosophy outside the analytic school through a flexible programme of specialist study. Study of Kant in the first semester is followed by a range of options (Adorno, Habermas, Hegel, Heidegger,

Kierkegaard, Marx, Schopenhauer, Wittgenstein). Each option focuses on a specific text. The programme is aimed at those who have studied philosophy at undergraduate level, but those without a formal background in philosophy can be considered.

Attendance is one/two evenings a week over two years at our Tottenham campus. Fee at present: $\mathbf{£} \mathbf{5 2 0}$ a year.

The programme is part of the Humanities MA degree scheme, which also includes programmes of study in history, literature and languages. 


\section{ROUTLEDGE}

\section{Pantheism}

\section{A Non-Theistic Concept of Deity}

\section{Michael P. Levine}

Levine presents the notion that everything is part of an all-inclusive divine unity as a legitimate position. He examines its philosophical foundations, and investigates some implications of pantheism in terms of practice.

June 1994: 216x138: 232pp $\mathrm{Hb}$ : 0-415-07064-3: $₫ 45.00$

\section{Vagueness}

\section{Timothy Williamson}

When did Rembrandt get old? Such questions eventually lead us to the problem of 'vagueness'. Williamson traces its history, questions conventional theories and defends the realist view that vagueness is a kind of ignorance.

"His effort takes epistemicism to a new level of depth and distinction."

- Roy Sorenson, New York University

July 1994: $216 \times 138: 288 p p \quad H b: 0-415-03331-4: £ 37.50$

\section{Using Sartre}

\section{An Analytical Introduction to Early Sartrean Themes Gregory McCulloch}

What can Sartre teach analytic philosophers? In a surprising and lively analysis Gregory McCulloch convincingly argues that analytic philosophy can learn a great deal from Sartre and the continental tradition in philosophy generally.

June 1994: 216x138: 160pp Hb: 0-415-10953-1: $\$ 35.00$

$\mathrm{Pb}:$ 0-415-10954-X: $£ 10.99$

New in Paperback

\section{Aquinas on Mind}

\section{Sir Anthony Kenny}

Kenny reveals how the mature thought of Thomas Aquinas although conceived in the thirteenth century has much to offer our understanding of the relationship between intellect and will, body and soul today.

September 1994: 216x138: 192pp Pb: 0-415-11306-7: $\{9.99$

\section{New in Paperback}

\section{Philosophical Essays}

\section{Bertrand Russell}

Now available for the first time in paperback, this collection of essays display all of Russell's clarity, incisiveness and brilliance of exposition, particularly on matters of ethics and the nature of truth.

"In the manner of self-restraint, clear statement and rigorous argument these essays are models of what such essays should be."

- The Glasgow Herald

March 1994: 216x138: 160pp Pb: 0-415-10579-X: £7.99

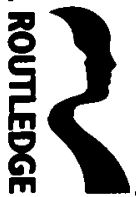

Available through booksellers. For more information or a FREE Philosophy catalogue, please contact Kevin Waudby, 11 New Fetter Lane, London EC4P 4EE. Tel: 071-842 2011 


\section{NEW IN 1994}

Self-Knowledge

AVAILABLE IN PAPERBACK

Edited by QUASSIM CASSAM

This volume brings together some of the most important and influential recent writings on knowledge of oneself and of one's own

thoughts,sensations, and experiences. It includes a specially commissioned essay by Sir Peter Strawson.

Oxford Readings in Philosophy

0-19-875115-X, 226 pages, $£ 30.00$

0-19-875116-8, paperback, $£ 9.95$

\section{Truth, Fiction, and Literature}

A Philosophical Perspective

PETER LAMARQUE and STEIN HAUGOM OLSEN

Examines the complex and varied ways in which fictions relate to the real world, offering a precise account of how imaginative works of literature can use fictional content to explore matters of universal human interest. Clarendon Library of Logic and Philosophy

0-19-824082-1, 494 pages, Clarendon Press, $£ 45.00$

\section{A Model of the Universe}

Space-Time, Probability, and Decision

STORRS MCCALL

An original philosophical theory of the nature of the universe based on a striking new model of its space-time structure.

Clarendon Library of Logic and Philosophy

0-19-824053-8, 338 pages, line figures, Clarendon Press, $£ 30.00$

\section{Raw Feeling}

A Philosophical Account of the Essence of Consciousness ROBERT KIRK

Using the notion of 'raw feeling' to bridge the gap between our knowledge of ourselves as physical organisms and as subjects of experience, Robert Kirk analyses the problem of consciousness and suggests a new way of solving it.

0-19-824081-3, 260 pages, Clarendon Press, $£ 27.50$

Available NOW from all good bookshops

To order direct: 8 (0536 741519) 24-hour credit-card hotline: 8 (0536 454534)

\section{OXFORD UNIVERSITY PRESS}




\section{the review of}

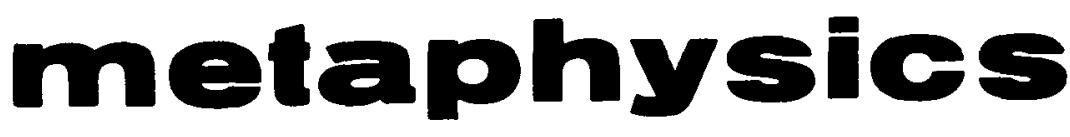

a philosophical quarterly

ISEN 00346632

SEPTEMBER 1993 | VOL. XLVII, No. 1 | ISSUE No. 185 | \$11.00

articles

books received

philosophical abstracts

doctoral dissertations

visiting philosophers

retiring philosophers

announcements

RALPH MGUNERNY

LILIANNE RIVKA KFIA

The Ontological Status of Mathematical

Entities

ARMAND MAURER

WAYNE WAXMAN

DONALD PHILLP VEAENE

IAN BELL AND STAFF

philosophical abstracts

onnouncements

Individual Subscriptions $\$ 25.00 \quad$ Institutional Subscriptions $\$ 42.00$ 


\section{Philosophy \& Social Criticism}

\begin{tabular}{|c|c|}
\hline $\begin{array}{l}\text { Focusing on: } \\
\text { O Continental Thought } \\
\text { @ American Philosophy } \\
\text { E Ethics } \\
\text { Law }\end{array}$ & $\begin{array}{l}\text { Hermeneutics } \\
\text { @ Literary Theory } \\
\text { Cultural Critique } \\
\ominus \text { Politics } \\
\text { Postmodernity }\end{array}$ \\
\hline
\end{tabular}

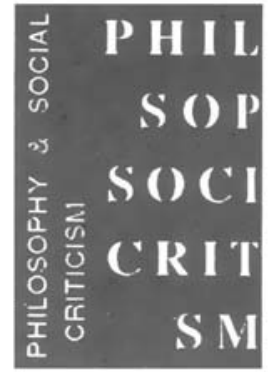

Volume 17 Number 4

Ingram •Basic Antinomies in Liberal Thought

Mousse -Rorty's Liberalism and the Radical Urge for a Philosophical Foundution

Matustik-Habermas Reading of Kierkegand: Notes from a Conversation

Jacques -A Study in Foucault's Genealogy

Feher-Moral Responsibility in Psychoanalytical Hemencurice

Volume 17 Number 3

Mourrain-Marx Textual Play with Women: The $\operatorname{Hom}(m)$-logistics of Intersubjectivity

Nussbaum -Habermas and Gruenbaum on the Logic of Psychoanalytic Explanations

Flynn-Places of the Work of Art in Arend's Philosophy

Bracken -Coercive Spaces and Spatial Coercions: Althusser and Foucault

Gandesha -The Theatre of the "Other": Adomo, Poststructuralism and the Critique of Identity

Volume 17 Number 2

Heller - Role of Interpretation in Modem Ethical Practice

Levin Phenomenology in America

Feher -Hermeneutics as Europe's Mainstream Political Moral Tradition

Shenz -Latin American Philosophies of Liberation and the Religions of the Oppressed

Volume 17 Number 1

Norris -The Gulf War, Postmodemism and Realpolitik

Simons -Resistance to Polaesthecs: Politics after Foucault

Negrin -Post-histoire: A Comparative Analysis of

Decadentism and Postmodemism

Philosophy \& Social Critlclom isolfering back issues at the following special prices:

-

nonsononspecial issues US\$9.95

Volume 16 Number 4

Ingram •Dworkin, Habermas, and the CLS Movement on Moral Criticism in Law

Cunningham•Democracy and Socialism: Philosophical Aporice

Popov -Coramunity and Utopia: A Transcendental Deducia Miller -Marxist Literary Aesthetics

Volume 16 Number 3

CorradbMetaphoric Structure of Sociological Explanmion

Barblero -The Roots of Ferry and Renaut's Huminim

Rockmore oMarx and Perestroika

Hoy •Contra Deconstructivism

Mosa-Ethical Expertise and Moral Maturity

Volume 16 Number 2

Ferrara.The Unbearable Seriousness of Irony

Bergoffen - The Body Politic

B a log-Max Hortheimer's Social Theory and Critique

Honneth.On the Anthropology of Claude LEvi-Strauss

Matustik •(editorial correction) Jilirgen Habermas at 60

Volume 16 Number 1

Hayim-Hegel's Critical Theory and Feminist Concems

Geiman -Lyotard's "Kantian Socialism"

Phelan -Adorno and Feminist Essentialism

Howard -A Response to Petrey

Corradi oreview: O Lomal Constituting a Self by Kurt Matu stik -Jikgen Habermas at 60 Wolff

\begin{tabular}{|c|c|}
\hline $\begin{array}{l}\text { Back issues } \\
\text { Single issues } \$ 3.00 \text { US } \\
\text { Special lssues } \$ 9.95 \text { US } \\
\text { full list available upon request } \\
\text { SEND CHECK PAYABLE } \\
\text { Name }\end{array}$ & $\begin{array}{l}\text { Current Subscription Rales: Volume } 19 \text { (1993) } \\
\text { Library } \\
\text { Individual } \\
\text { \$30 US \& Canada / } \$ 88 \text { Foreign } \\
\text { Full time Student } \$ 25 \text { US \& Canada / } \$ 33 \text { Foreign } \\
\text { PHILOSOPHY AND SOCIAL CRITICISM }\end{array}$ \\
\hline Mailing address & \\
\hline $\begin{array}{l}\text { State or } \\
\text { Mail to:Philosophy \& } \\
\text { Dept of Philosophy, Bo }\end{array}$ & $\begin{array}{l}\text { Zip Code Country } \\
\text { I Criticism; David Rasmussen, Editor } \\
\text { College, Chestnut Hill, MA, 02167, USA }\end{array}$ \\
\hline
\end{tabular}




\section{KURT FLASCH \\ Was ist Zeit?}

Augustinus von Hippo. Das XI. Buch der Confessiones. Historisch-philosophische Studie. Text - Übersetzung - Kommentar

1993. 438 Seiten. Ln DM 98.- ISBN 3-465-02618-7 Kt DM 68.- ISBN 3-465-02617-9

Das XI. Buch von Augustins Confessiones ist der meistdiskutierte Text der spätantiken Philosophie. Husserl, Heidegger und Wittgenstein sahen in ihm das klassische Dokument zur Philosophie der Zeit.

Die Abhandlung von Kurt Flasch setzt ein mit der Analyse der Gründe, die im 20. Jahrhundert zu einer erneuten Hinwendung zu Augustins Zeittheorie geführt haben, wendet sich dann aber, um einseitigen Aktualisierungen zu entgehen, dem literarischen Ort und der Stellung des XI. Buches in der Entwicklung des Augustinischen Denkens zu. Flasch analysiert sodann Augustins Theorie im Kontext des spätantiken Denkens und geht insbesondere den Beziehungen zu Plotin und zur skeptischen Tradition nach. Er beleuchtet erstmals Augustins Zeittheorie aus den Debatten, die sie im Mittelalter ausgelöst hat.

Die Arbeit ist nicht im engeren Sinne „philosophiehistorisch“ angelegt, sondern sie analysiert Augustins Zeittheorie als ein denkgeschichtliches Arbeitsfeld. Dabei bemüht sie sich um Textnähe und philologische Präzision. Daher enthält dieses Buch ferner: Augustins Text Confessiones XI. in der lateinischen Version von L. Verheijen, eine neue deutsche Übersetzung, einen ausführlichen historisch-philosophischen Kommentar, der die Argumentation Augustins im Detail untersucht.

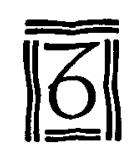

VITTORIO KLOSTERMANN · FRANKFURT AM MAIN 


\title{
Unzeitgemäße Hermeneutik
}

\author{
Verstehen und Interpretation im Denken der Aufklärung \\ Herausgegeben von Axel Bühler \\ 1994. VI, 276 Seiten. Ln DM 98.- ISBN 3-465-02632-2
}

Ein zentrales Thema im Denken der Aufklärung, vor allem im 18. Jahrhundert, war die Methodologie der Interpretation von Text und Rede. In dieser Zeit wurde die Zielvorstellung des historisch-kritischen Herangehens an die Tradition klar formuliert. Man betonte gleichzeitig die Universalität der Prozesse des Auslegens und Verstehens und dehnte das Ideal der systematischen Wissensorganisation des klassischen Rationalismus auf die Methodenlehre der Auslegung aus. Bisher hat die Geschichtsschreibung die Hermeneutik der Aufklärung stark vernachlässigt. Der vorliegende Band soll dieser Situation abhelfen.

Die Hermeneutik der Aufklärung ist ,unzeitgemäßs, weil sie in ihrer Insistenz auf der Möglichkeit hermeneutischer Ojektivität und dem Auslegungsziel der Auffindung der Autorintention im Widerspruch zu Strömungen des hermeneutischen Denkens des 20. Jahrhunderts steht, so etwa zu der Philosophischen Hermeneutik Gadamers und Heideggers. Mit der Rückbesinnung auf die heute kontroversen Standpunkte der Hermeneutik der Aufklärung soll der vorliegende Band auch zur hermeneutischen Grundlagendiskussion beitragen.

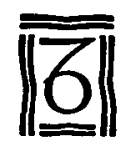

VIT'TORIO KLOSTERMANN - FRANKFURT AM MAIN 


\section{CAMBRIDGE}

\section{Liberal Rights}

Collected Papers 1981-1991

JEREMY WALDRON

This volume brings together a wide-ranging collection of the papers written

by Jeremy Waldron, one of the most internationally respected political theorists writing today.

f40.00 net $H B \quad 0521430240 \quad 482 \mathrm{pp}$.

£12.95 net PB 0521436176

Cambridge Studies in Philosophy and Public Policy

\section{The Critical Mass in Collective Action}

A Micro-Social Theory

GERALD MARWELL and PAMELA OLIVER

This book analyses the social pressure whereby groups solve the problem of collective action.

f27.95 net HB 0521308399224 pp.

Studies in Rationality and Social Change

\section{The Search for a Naturalistic World View}

Volume I: Scientific Method and Epistemology

\section{ABNER SHIMONY}

This two-volume collection of Abner Shimony's essays written over a period of forty years explores the interrelations between science and philosophy.
⿷37.50 net
HB
0521373522
$368 \mathrm{pp}$
f12.95 net
PB $\quad 0521377447$

\section{The Search for a Naturalistic World View}

Volume II: Natural Science and Metaphysics

ABNER SHIMONY

$£ 37.50$ net HB $0521373530 \quad 360$ pp.

f12.95 net PB 0521377455

\section{Altruism}

Edited by ELLEN FRANKEL PAUL, FRED D. MILLER Jr., and JEFFREY PAUL This collection of essays on moral philosophy deals with the balance to be struck between egoism and altruism - that is between pursuing one's own interests and serving the interest of others - and with related issues.
f12.95 net
PB
0521447593
256 pp.

Social Philosophy and Policy 10: 1
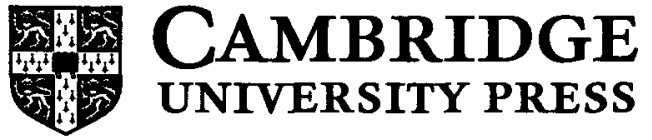

The Edinburgh Building, Cambridge CB2 2RU 


\section{CAMBRIDGE}

\section{The Cambridge Companion to Hegel}

\section{Edited by FREDERICK C. BEISER}

This volume considers all the major aspects of Hegel's work: epistemology, logic, ethics, political philosophy, aesthetics, philosophy of history, philosophy of religion.

f40.00 net HB $0521382742 \quad 592 \mathrm{pp}$.

f12.95 net PB 0521387116

Cambridge Companions to Philosophy

\section{The Cambridge Companion to Heidegger} Edited by CHARLES GUIGNON

This volume contains both overviews of Heidegger's life and works and analysis of his most important work, Being and Time.

f37.50 net HB $0521385709 \quad 432 \mathrm{pp}$.

f12.95 net PB 0521385970

Cambridge Companions to Philosophy

\section{Kant and the Experience of Freedom}

Essays on Aesthetics and Morality

PAUL GUYER

This collection of essays by one of the pre-eminent Kant scholars of our time transforms our understanding of both Kant's aesthetics and his ethics. f45.00 net HB $0521414318 \quad 480 \mathrm{pp}$.

\section{Francis Hutcheson: Two Texts on Human Nature} Edited by THOMAS MAUTNER

Two texts by a leading figure in British moral philosophy, supported by a mass of background information.

f30.00 net HB $0521430895208 \mathrm{pp}$.

\section{Marxism Recycled}

PHILIPPE VAN PARIJS

Van Parijs defends the notion of a 'capitalist road to communism', remaining true to the Marxian ideal while embracing capitalism.

f27.95 net HB $052141802 \times 416 \mathrm{pp}$.
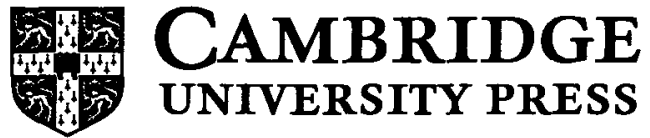

The Edinburgh Building, Cambridge CB2 2RU 


\section{CAMBRIDGE}

\section{Practical Ethics}

\section{Second Edition}

\section{PETER SINGER}

Peter Singer's remarkably clear and comprehensive Practical Ethics has become a classic introduction to applied ethics since its publication in 1979. For this second edition the author has revised all the existing chapters, added two new ones, and updated the bibliography.

f30.00 net HB $0521433630 \quad 416 \mathrm{pp}$.

€9.50 net PB $052143971 X$

\section{The Ethics and Politics of Human Experimentation}

Edited by PAUL M. MCNEILL

This book focuses on experimentation that is carried out on human beings, including medical research, drug research and research undertaken in the social sciences.

f35.00 net HB $0521416272 \quad 328 \mathrm{pp}$.

\section{Life and Death}

Philosophical Essays in Biomedical Ethics

DAN W. BROCK

In this collection, Dan Brock, a distinguished philosopher and bioethicist and coauthor of Deciding for Others (Cambridge, 1989), explores the moral issues raised by new ideals of shared decision making between physicians and patients.

f42.50 net HB $0521417856 \quad 480$ pp.

f14.95 net PB 0521428335

Cambridge Studies in Philosophy and Public Policy

\section{Now in paperback}

\section{A Morally Deep World}

An Essay on Moral Significance and Environmental Ethics LAWRENCE E. JOHNSON

Lawrence Johnson advocates a major change in our attitude towards the non-human world, arguing that nonhuman animals, and eco-systems themselves, are morally significant beings with interests and rights.

f10.95 net PB $0521447062300 \mathrm{pp}$.

\section{Morality, Prudence, and Nuclear Weapons} STEVEN P. LEE

This book is the first post Cold War assessment of nuclear deterrence, providing a comprehensive normative understanding of nuclear deterrence policy, and examining both its ethical and strategic dimensions.

f45.00 net HB $0521382726 \quad 448$ pp.

Cambridge Studies in Philosophy and Public Policy
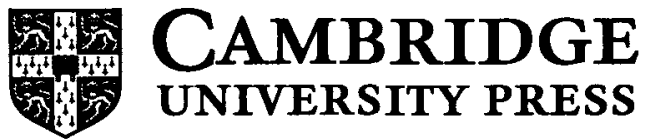

The Edinburgh Building, Cambridge CB2 2RU 


\section{CAMBRIDGE}

\section{Early Philosophical Shiism}

The Ismaili Neoplatonism of Abu Ya'qub al-Sijistani

PAUL E. WALKER

This is the first book-length study of the ideas and teachings of the leading tenth-century Ismaili theoretician Abu Ya'qub al-Sijistani.

f30.00 net HB 0521441293219 pp.

Cambridge Studies in Islamic Civilzation

\section{The Epistemology of Religious Experience}

KEITH E. YANDELL

Keith Yandell argues against the notion that religious experience is ineffable, while advocating the view that strong numinous experience provides some evidence that God exists.

f35.00 net HB $052137426 \times \quad 469$ pp.

\section{Explanation and Value in the Arts}

Edited by SALIM KEMAL and IVAN GASKELL

Penetrating studies by a group of art historians, literary theorists, and philosophers consider 'explanation' and works of literature and painting. f35.00 net HB 0521419263256 pp.

Cambridge Studies in Philosophy and the Arts

\section{Landscape, Natural Beauty, and the Arts}

Edited by SALIM KEMAL and IVAN GASKELL

A distinguished group of scholars here probes the complex structure of aesthetic responses to nature, in a discussion enriched with insights from art history, literary criticism, geography and philosophy.

f37.50 net HB 0521432790288 pp.

Cambridge Studies in Philosophy and the Arts

\section{The Fine Art of Repetition}

Essays in the Philosophy of Music

PETER KIVY

This collection of essays from Peter Kivy span a period of some thirty years and focus on a richly diverse set of issues providing an enjoyable and insightful to the philosophy of art and music.
£ 37.50 net
$\mathrm{HB}$
0521434629
$384 \mathrm{pp}$.
f13.95 net
PB $\quad 0521435986$

\section{CAMBRIDGE \\ UNIVERSITY PRESS}

The Edinburgh Building, Cambridge CB2 2RU 


\section{Information for Authors}

Prospective authors should send their contributions, typed and doublespaced on quarto or A4 paper, to the Editor, Mr Renford Bambrough, Royal Institute of Philosophy, 14 Gordon Square, London WC1H 0AG. They should retain a second copy for the purpose of checking proofs. Articles submitted should conform to Hart's Rules for Compositors and Readers (Oxford Lniversity Press, 1967). The Editor may alter manuscripts wherever necessary to make them conform to the stylistic and bibliographical conventions of the journal. Single quotation marks should be used except where there is a quotation within another. The titles of books and journals should be underlined (i.e. to be printed in italics), as should foreign words. Titles of articles should be in single quotation marks.

Notes and references will be printed as footnotes and should be typed (double-spacing) on a separate sheet, numbered consecutively. They should be referred to in the text by superscripts. Citations should be as follows:

'H. B. Acton, The Philosophy of Punishment (London: Macmillan, 1969), 192-198.

${ }^{2}$ R. S. Downie and Elizabeth Telfer, 'Autonomy', Philosophy' 46, No. 178 (October 1971), 295.

Op. cit. note 1, 101-112.

'W. C. Wimsatt, 'Some Problems with the Concept of Feedback', Boston Studies in the Philosophy' of Science, VIII, R. C. Buck and R. S. Cohen (eds.) (Dordrecht: D. Reidel, 1971), 242.

The return of contributions cannot be guaranteed unless they are accompanied by stamps, or in the case of contributions from abroad, by international coupons, to cover postage. A self-addressed envelope should also be enclosed.

Only corrections of printer's errors can be allowed in proofs. Authors are therefore asked to send any alterations or additions to Mr Bambrough as soon as possible after receiving his letter of acceptance.

Authors of articles, discussion papers and review articles will receive twenty-five offprints free of charge. Additional offprints can be ordered when proofs are returned by arrangement with the Institute.

Books for review should be sent to the Editor at the Institute and not to Cambridge University Press. Publishers are asked to note that nonphilosophical works are not reviewed in Philosophy.

Authors' corrected proofs should be sent to Mr Bambrough at St John's College, Cambridge. All other correspondence should be addressed to the Institute and not to any address in Cambridge.

\section{CAMBRIDGE UNIVERSITY PRESS}

The Pitt Building, Trumpington Street, Cambridge CB2 1RP

40 West 20th Street, New York, NY 10011-4211, LSA

10 Stamford Road, Oakleigh, Melbourne 3166, Australia 


\section{Philosophy}

VOLUME 69 NO 269 JULY 1994

Editorial: Let there be Finesse

So You Think You Are a Darwinian? - DAvid STOVE 267

What's Old in Derrida? - IDDO LANDAU 279

Aristotelian Virtue and Its Limitations - CHRISTOPHER CORDNER 291

St Augustine and the Paradox of Reflection-ROGER McLURE 317

Wittgenstein's Romantic Inheritance -

M. W. ROWE

Ten Answers For Psycho-analysis - ILHAM DiLmAN

Discussion

Champlin on a Curious Plural - C. J. F. Williams

More About Infinite Numbers - P. O. JOHNSON

Confidence Tricks - ROGER SQUIRES

New Books

Reviews

Booknotes

Books Received

Notebook

(C) The Royal Institute of Philosophy 1994

Typeset by Michael Heath Limited, Reigate, Surrey Printed in Great Britain by the University Press, Cambridge

\section{CAMBRIDGE} UNIVERSITY PRESS

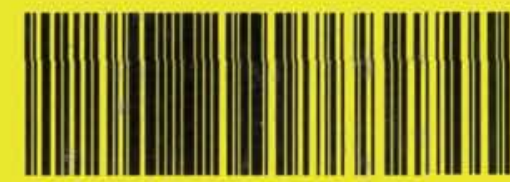

